\title{
OMI satellite observations of decadal changes in ground-level sulfur dioxide over North America
}

\author{
Shailesh K. Kharol ${ }^{1}$, Chris A. McLinden ${ }^{1}$, Christopher E. Sioris ${ }^{1}$, Mark W. Shephard ${ }^{1}$, Vitali Fioletov ${ }^{1}$, \\ Aaron van Donkelaar ${ }^{2}$, Sajeev Philip ${ }^{2, a}$, and Randall V. Martin ${ }^{2,3}$ \\ ${ }^{1}$ Air Quality Research Division, Environment and Climate Change Canada, Toronto, Ontario M3H 5T4, Canada \\ ${ }^{2}$ Department of Physics and Atmospheric Science, Dalhousie University, Halifax, Nova Scotia, Canada \\ ${ }^{3}$ Harvard-Smithsonian Center for Astrophysics, Cambridge, Massachusetts, USA \\ ${ }^{a}$ now at: NASA Ames Research Center, Moffett Field, California, USA
}

Correspondence to: Shailesh K. Kharol (shailesh.kharol@canada.ca)

Received: 29 November 2016 - Discussion started: 5 December 2016

Revised: 9 March 2017 - Accepted: 12 April 2017 - Published: 15 May 2017

\begin{abstract}
Sulfur dioxide $\left(\mathrm{SO}_{2}\right)$ has a significant impact on the environment and human health. We estimated groundlevel sulfur dioxide $\left(\mathrm{SO}_{2}\right)$ concentrations from the Ozone Monitoring Instrument (OMI) using $\mathrm{SO}_{2}$ profiles from the Global Environmental Multi-scale - Modelling Air quality and CHemistry (GEM-MACH) model over North America for the period of 2005-2015. OMI-derived ground-level $\mathrm{SO}_{2}$ concentrations $(r=0.61)$ and trends $(r=0.74)$ correlated well with coincident in situ measurements from air quality networks over North America. We found a strong decreasing trend in coincidently sampled ground-level $\mathrm{SO}_{2}$ from OMI $(-81 \pm 19 \%)$ and in situ measurements $(-86 \pm 13 \%)$ over the eastern US for the period of 2005-2015, which reflects the implementation of stricter pollution control laws, including flue-gas desulfurization (FGD) devices in power plants. The spatially and temporally contiguous OMI-derived ground-level $\mathrm{SO}_{2}$ concentrations can be used to assess the impact of long-term exposure to $\mathrm{SO}_{2}$ on the health of humans and the environment.
\end{abstract}

\section{Introduction}

Sulfur dioxide $\left(\mathrm{SO}_{2}\right)$ is a short-lived atmospheric trace gas emitted into the atmosphere from natural (e.g. volcanic eruption, oxidation of dimethylsulfate (DMS) over oceans) and anthropogenic sources (e.g. combustion of fossil fuels and smelting of sulfur-containing metal ores), and plays a pivotal role in the global sulfur cycle. $\mathrm{SO}_{2}$ has a short life- time of hours to days, and it oxidizes quickly in the atmosphere to produce sulfate aerosols that affect the climate (IPCC, 2013) and the environment from local to regional and global scales. Sulfate aerosols are a major contributor to $\mathrm{PM}_{2.5}$ (particulate matter with aerodynamic diameter $<2.5 \mu \mathrm{m}$ ) chemical composition and account for 17 and $\sim 30 \%$ of the annual mean $\mathrm{PM}_{2.5}$ mass globally and over the eastern United States (Philip et al., 2014). Sulfate aerosol formation leads to degradation in visibility and air quality (van Donkelaar et al., 2008) and deposition of sulfuric acid (Dentener et al., 2006; Vet et al., 2014), and poses a serious health hazard to the general population (Lee et al., 2015). The increased risk of premature mortality associated with $\mathrm{SO}_{2}$ alone or its secondary pollutants has been emphasized in several epidemiological studies (Chinn et al., 1981; Derriennic et al., 1989; Hatzakis et al., 1986; Krzyzanowski and Wojtyniak, 1982). Furthermore, it has been recently reported by Lelieveld et al. (2015) using the EMAC (ECHAM5/MESSy Atmospheric Chemistry) general circulation model that in the US, in addition to agricultural emissions (an important source of ammonia, $\mathrm{NH}_{3}$ ), emission from coal-fired power plants (an important source of $\mathrm{SO}_{2}$ and nitrogen oxides, $\mathrm{NO}_{x}$ ) was the largest contributor to premature mortality in 2010 . Due to the adverse impact on the environment and human health, $\mathrm{SO}_{2}$ and its oxidation products (i.e. fine particulate matter, $\mathrm{PM}_{2.5}$ ) are considered designated criteria pollutants in the European Union (European Commission, http://ec.europa.eu/environment/ air/quality/standards.htm), the United States of America (US 
Environmental Protection Agency (EPA), https://www.epa. gov/criteria-air-pollutants) and Canada (https://www.ec.gc. ca/Air/default.asp?lang=En\&n=7C43740B-1).

Globally, atmospheric $\mathrm{SO}_{2}$ is monitored regularly through a relatively small number of measurement networks that produce accurate measurements but over a limited spatial area. Satellite measurements have the advantage of providing complete daily global coverage of $\mathrm{SO}_{2}$. Satellite observations of $\mathrm{SO}_{2}$ vertical column density (VCD) began in the 1980s, but the launch of the Ozone Monitoring Instrument (OMI) (Krotkov et al., 2006; Yang et al., 2007) on the Aura satellite in 2004 has enabled large point sources to be resolved with its higher spatial resolution $\left(13 \times 24 \mathrm{~km}^{2}\right.$ at nadir) (Fioletov et al., 2013). Satellite measurements of $\mathrm{SO}_{2}$ have been used to identify and analyze emissions (Fioletov et al., 2011, 2013, 2015, 2016; Lee et al., 2011; McLinden et al., 2016a), track changes in total column density in various regions, including Canadian oil sands, the eastern US, eastern Europe, eastern China, India and the Middle East (McLinden et al., 2016b; Krotkov et al., 2016), and estimate dry deposition flux (Nowlan et al., 2014). In previous studies (Lee et al., 2011; Nowlan et al., 2011), ground-level $\mathrm{SO}_{2}$ concentrations were estimated for only a 1 -year period using satellite observations over North America. However, multi-year spatial variations in ground-level $\mathrm{SO}_{2}$ have not yet been assessed from the satellite observations. In contrast to total column $\mathrm{SO}_{2}$, long-term records of ground-level $\mathrm{SO}_{2}$ concentrations from satellite observations will be directly useful to assess air quality and associated health risks. Recently, a decreasing trend in $\mathrm{SO}_{2}$ emissions and particulate sulfate has been reported by Hand et al. (2012) over the United States from the early 1990s through 2010.

In this paper we first describe the $\mathrm{OMI} \mathrm{SO}_{2}$ product, in situ measurement network, the GEM-MACH (Global Environmental Multi-scale - Modelling Air quality and Chemistry) air quality model, ground-based $\mathrm{SO}_{2}$ estimation from the OMI and trend analysis. We then use these data and this methodology to estimate ground-level $\mathrm{SO}_{2}$ from the $\mathrm{OMI}$ and evaluate it with coincident in situ measurements over North America for the period of 2005-2015. These results are then used to determine the trend in ground-level $\mathrm{SO}_{2}$ from both OMI and collocated in situ measurements.

\section{Data sets and methodology}

\subsection{OMI}

The OMI is a nadir-viewing UV-visible spectrometer boarded on the Aura satellite that was launched in July 2004 and is part of the NASA A-train constellation (Levelt et al., 2006). The Aura satellite overpasses the Equator in the early afternoon (13:00-14:30 local time) in a sunsynchronous ascending polar orbit. The OMI provides daily global coverage of aerosols and trace gases, including $\mathrm{SO}_{2}$, with a variable ground spatial resolution of $13 \mathrm{~km} \times 24 \mathrm{~km}$ at nadir to $140 \mathrm{~km} \times 26 \mathrm{~km}$ at swath edge. We use the OMI operational principal component analysis (PCA) $\mathrm{SO}_{2}$ product (OMSO2 v1.2.0), which is publicly available from the NASA Goddard Earth Sciences (GES) Data and Information Services Center (DISC) (http://disc.sci.gsfc.nasa.gov/Aura/ data-holdings/OMI/omso2_v003.shtml). The details of the PCA algorithm can be found elsewhere (Li et al., 2013). In brief, this algorithm applies the PCA technique to OMImeasured radiances between 310.5 and $340 \mathrm{~nm}$ to extract principal components from each row of data on an orbital basis. The PCA algorithm replaced the band residual difference (BRD) algorithm (Krotkov et al., 2006) as the operational algorithm for the standard $\mathrm{OMI} \mathrm{SO}_{2}$ data because only the latter algorithm was biased (Fioletov et al., 2013; Krotkov et al., 2016). Also, $\mathrm{SO}_{2}$ retrieval variability is reduced by a factor of 2 in the PCA algorithm relative to the BRD algorithm (Li et al., 2013). Even though the PCA algorithm directly estimates $\mathrm{SO}_{2}$ vertical column density in one step using $\mathrm{SO}_{2}$ Jacobians, the air mass factor (AMF) is effectively fixed at 0.36 (representing summertime conditions in the eastern USA), similar to the BRD algorithm. A better estimation of AMFs is needed for different regions to reduce these systematic errors that result from conditions that do not match these. For this, we re-calculated the AMFs using $\mathrm{SO}_{2}$ profile information from the high-resolution $(15 \mathrm{~km} \times 15 \mathrm{~km}) \mathrm{GEM}$ MACH air quality forecast model (discussed in Sect. 2.3), monthly-varying surface reflectivity from the MODIS satellite instruments, and an improved identification of snow. More details on Environment Canada air mass factor calculation for $\mathrm{SO}_{2}$ are discussed in McLinden et al. (2014, 2016b). Here, we exclude the cross-track pixels affected by the row anomaly (http://www.knmi.nl/omi/research/product/ rowanomaly-background.php), which was first noticed in the data in June 2007. We use OMI SO 2 columns with cloud radiance fractions $<0.2$, and solar zenith angles $<65^{\circ}$ following Nowlan et al. (2014). We exclude from the analysis the $\mathrm{OMI} \mathrm{SO}_{2}$ data affected by the largest northern mid-latitude volcanic eruptions in the OMI time frame, namely Kasatochi (Aleutian Islands, Alaska, August 2008, 52 ${ }^{\circ} \mathrm{N}$ ) and Sarychev (Kuril Islands, eastern Russia, June $2009,48^{\circ} \mathrm{N}$ ). Here, we used the mean OMI values over a $32 \mathrm{~km}$ averaging radius (Fioletov et al., 2011) that is oversampled onto a $0.1^{\circ} \times 0.1^{\circ}$ latitude-longitude grid.

\section{$2.2 \quad \mathrm{SO}_{2}$ monitoring networks}

To evaluate the OMI-derived ground-level $\mathrm{SO}_{2}$ we use hourly in situ $\mathrm{SO}_{2}$ measurements from the Air Quality System (AQS) network of the US EPA (http://www.epa.gov/ttn/ airs/airsaqs/detaildata/downloadaqsdata.htm) and Environment and Climate Change Canada's National Air Pollution Surveillance (NAPS) network (http://maps-cartes.ec.gc.ca/ rnspa-naps/data.aspx) over the US and Canada for the period of 2005-2015. US-EPA AQS site locations vary from 
regional background to urban and industrial locations, and measure $\mathrm{SO}_{2}$ using continuous gas monitors. The Canadian NAPS sites are generally located in populated areas. The hourly in situ measurements are averaged over a $2 \mathrm{~h}$ period (13:00-15:00 local time) to correspond to the satellite observation times over North America.

\subsection{Model information}

We use the Global Environmental Multi-scale - Modelling Air quality and CHemistry (GEM-MACH) model for the tropospheric $\mathrm{SO}_{2}$ profile to relate the $\mathrm{OMI} \mathrm{SO}_{2}$ column to ground-level concentrations. GEM-MACH is the Canadian regional air quality forecast model used operationally to predict the concentrations of $\mathrm{O}_{3}, \mathrm{NO}_{2}$, and $\mathrm{PM}_{2.5}$ over North America (Moran et al., 2010; Gong et al., 2015). The GEMMACH model utilizes emissions inventories from US EPA and Environment Canada data for the year 2006. It uses detailed tropospheric processes for gas and particle chemistry and microphysics originating in the offline AURAMS model (A Unified Regional Air-quality Modelling System; Gong et al., 2006), and incorporates them online into the Canadian weather forecast model (Global Environmental Multiscale model, Côté et al., 1998). A detailed description of the chemical processes found in AURAMS and GEM-MACH is provided elsewhere (Kelly et al., 2012). The results used here are from archived forecasts from 2010 to 2011 for a domain covering North America at $15 \mathrm{~km} \times 15 \mathrm{~km}$ resolution. The lowest model layer, which is $20 \mathrm{~m}$ thick, is taken as the ground-level concentration.

\subsection{Estimation of ground-level $\mathrm{SO}_{2}$ from the OMI}

The ground-level $\mathrm{SO}_{2}$ mixing ratio from the OMI is estimated using the approach described by Lamsal et al. (2008) over North America for the period of 2005-2015. The ground-level $\mathrm{SO}_{2}$ mixing ratio $S$ is estimated from the local OMI tropospheric $\mathrm{SO}_{2}$ column $\Omega$ as

$S_{\mathrm{OMI}}=\Omega_{\mathrm{OMI}} \times \frac{S_{\text {model }}}{\Omega_{\text {model }}}$.

The subscript model represents the GEM-MACH model. More details on the procedure are discussed in McLinden et al. (2014).

\subsection{Trend analysis}

We analyzed the trends in monthly ground-level $\mathrm{SO}_{2}$ over North America from OMI and in situ measurements for the period of January 2005-December 2015. We applied a general least squares regression following Boys et al. (2014) and Kharol et al. (2015) using the basic model

$\boldsymbol{x}=\mathbf{z} \boldsymbol{\beta}+\boldsymbol{e}, \boldsymbol{e} \sim N\left(0, \sigma^{2} \mathbf{V}\right)$,

where, for a time series of $n$ months, $\boldsymbol{x}$ is a time series vector $(n \times 1)$ containing $\mathrm{SO}_{2}$ surface mixing ratio values; $\mathbf{z}$ is a de- sign matrix $(n \times 2)$ for the linear model; $\boldsymbol{\beta}$ is a vector $(2 \times 1)$ containing the intercept and slope of the linear model; $\boldsymbol{e}$ is an error vector $(n \times 1)$ containing the residuals which, for validity, should be approximately normally distributed with zero mean, but which is permitted to covary with adjacent values according to $\mathbf{V}$ - a positive definite, symmetric covariance matrix, to accommodate possible autocorrelation between adjacent months. Correlated errors between adjacent months are represented by a first-order autoregressive model of $\boldsymbol{e}$, which can be expressed as

$e_{t}=\varnothing e_{t-1}+w_{t} \quad t=1, \ldots n, \boldsymbol{w} \sim N\left(0, \sigma^{2} I\right)$,

where the residual $e_{t}$ for month $t$ is a fraction $\varnothing$ of the previous month's residual $e_{t-1}$ with a white noise component $w_{t}$ which, for validity, should be approximately normally distributed with zero mean, constant variance and be independent $I$. We deseasonalized the monthly time series by subtracting the climatological monthly median prior to regression. Note that the trend is more heavily weighted toward summer, when observations are more frequent.

\section{Results and discussion}

Figure 1 shows the spatial distribution of mean OMI-derived ground-level $\mathrm{SO}_{2}$ over North America for the periods of 2005-2007, 2008-2010, 2011-2015 and 2005-2015. The major $\mathrm{SO}_{2}$ hotspots (that is, locations of high $\mathrm{SO}_{2}$ associated with a large nearby source) are primarily located in the eastern US from coal-fired power plants and industrial activities (Krotkov et al., 2016). There are far fewer sources in the western US and Canada, with a few notable exceptions such as Flin Flon $\left(54.77^{\circ} \mathrm{N}, 101.88^{\circ} \mathrm{W}\right.$; copper smelter), Sudbury $\left(46.52^{\circ} \mathrm{N}, 80.95^{\circ} \mathrm{W}\right.$; copper and nickel smelter), Thompson $\left(55.74^{\circ} \mathrm{N}, 97.85^{\circ} \mathrm{W}\right.$; metal ore mining), Montreal $\left(45.50^{\circ} \mathrm{N}, 73.56^{\circ} \mathrm{W}\right)$, the oil sands region in northern Alberta and power plants nearby Edmonton. The spatial distribution of annual mean OMI-derived ground-level $\mathrm{SO}_{2}$ for each year is shown in supporting information in Fig. S1 in the Supplement. A noticeable decrease in OMI-derived ground-level $\mathrm{SO}_{2}$ is apparent from Fig. 1 during 2008-2010 and 2011-2015 compared to 2005-2007. These US reductions correspond to the installation of flue-gas desulfurization (FGD) units at many power plants to meet stricter emissions limits introduced by the Clean Air Interstate Rule. The closure of Flin Flon $\left(54.77^{\circ} \mathrm{N}, 101.88^{\circ} \mathrm{W}\right)$ copper smelter in June 2010 is also apparent in OMI-derived ground-level $\mathrm{SO}_{2}$ during 2011-2015 (Fig. 1). The OMI-derived ground-level $\mathrm{SO}_{2}$ concentrations over a large geographical area could be useful to assess its impact on human health and environment. It can also provide valuable information to policy makers where air quality network measurements are not available.

To verify these satellite findings, we compared the OMIderived ground-level $\mathrm{SO}_{2}$ concentrations with in situ measurements over North America for the period of 2005-2015. 
$\mathrm{OMI} \mathrm{SO}_{2}$ surface mixing ratio
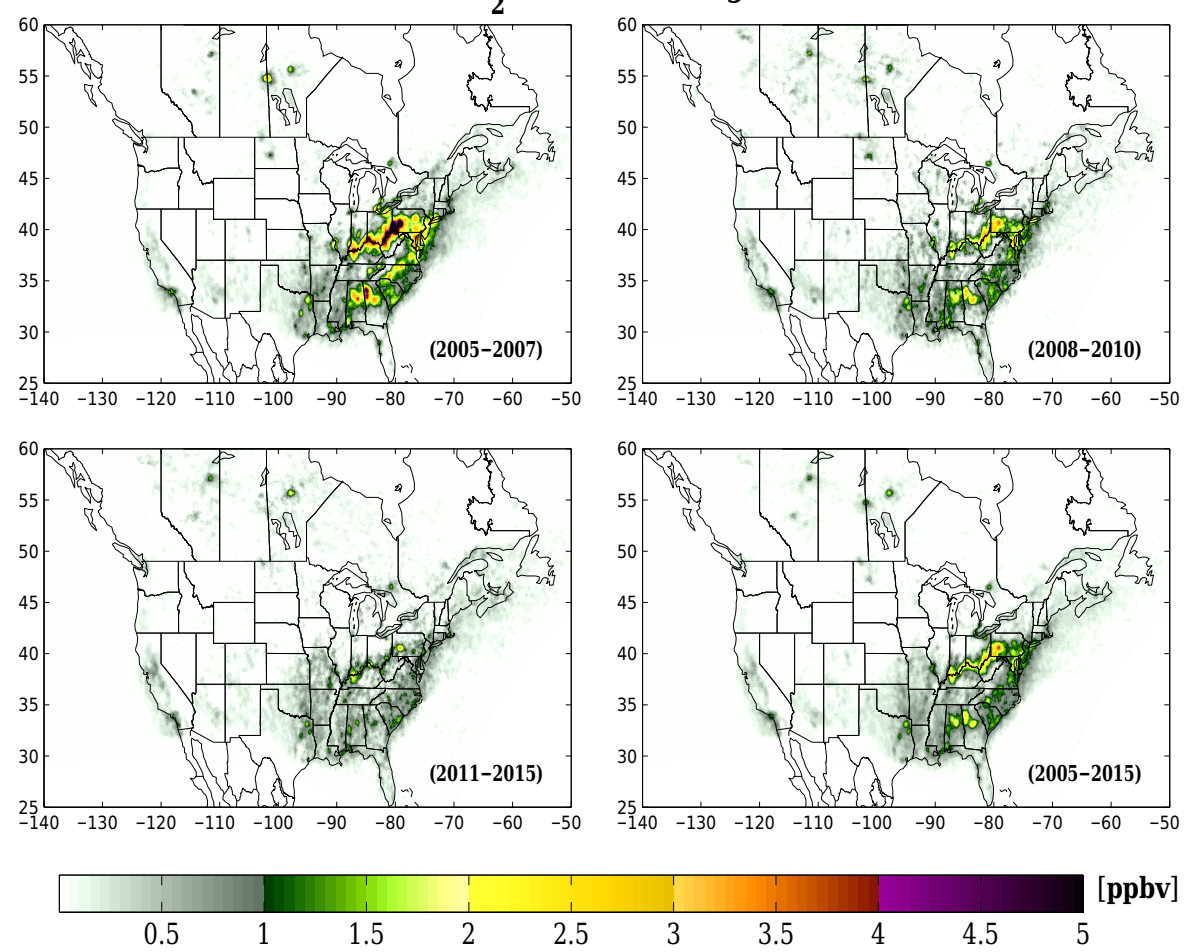

Figure 1. Spatial distribution of the mean OMI-derived ground-level $\mathrm{SO}_{2}$ mixing ratio over North America for the periods of 2005-2007, 2008-2010, 2011-2015 and 2005-2015.

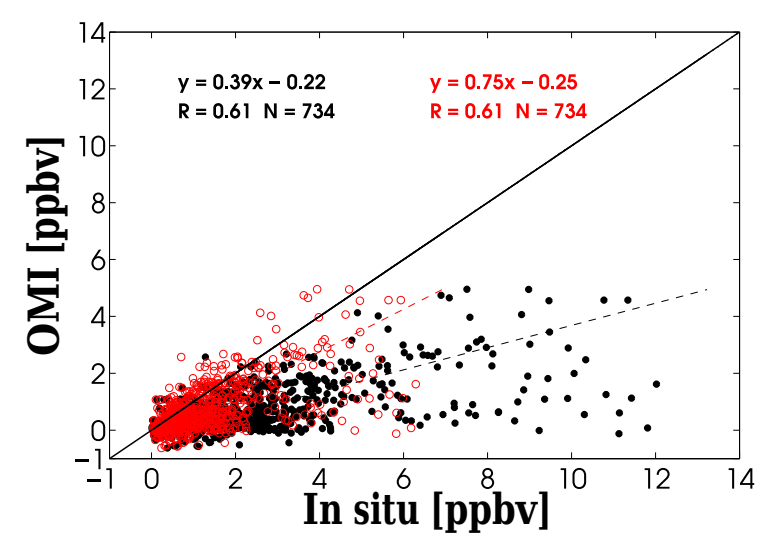

Figure 2. Scatter plot of the annual mean OMI-derived ground-level $\mathrm{SO}_{2}$ versus collocated in situ measurements for the years of 20052015. Filled black circles represent the original in situ values, and red circles represent the comparison with spatially inhomogeneity adjusted in situ values.

The original OMI-derived ground-level $\mathrm{SO}_{2}$ concentration (black circles) moderately correlates with collocated in situ measurements $(r=0.61)$, but has a significant difference in slope (slope $=0.39$ ) (Fig. 2). The departure from unity of the slope is a common feature of virtually all satellitesurface comparisons of this kind (Kharol et al., 2015), and can be a result of both the in situ monitor placements (i.e. mainly located in the cities and close to pollution sources) and differences in the spatial sampling of the two types of observations. To quantify this inhomogeneity effect we utilized output from the GEM-MACH model at high resolution $(2.5 \mathrm{~km} \times 2.5 \mathrm{~km}$; supporting information in Fig. S2) over a region in central Canada. These high-resolution GEM$\mathrm{MACH} \mathrm{SO}{ }_{2}$ columns at the locations of the in situ monitors were taken as representative of point (in situ) measurements. The model $\mathrm{SO}_{2}$ columns were then progressively averaged up (smoothed) to $30 \mathrm{~km} \times 30 \mathrm{~km}$, approximately representing the spatial size of an OMI pixel. The smoothed columns are regressed against the unsmoothed columns. The slope and correlation coefficient continue to decrease from unity as the smoothing is increased. We used this estimate of the spatial inhomogeneous sampling obtained from the original $(2.5 \mathrm{~km})$ vs. smoothed $(30 \mathrm{~km})$ GEM-MACH $\mathrm{SO}_{2}$ column (supporting information in Fig. S3) to derive a scaling factor (in situ scaled $=0.52 \times$ (in situ) $+0.04, R=0.83$ ) that is used to adjust the in situ measurements to be representative of the OMI pixel size over all of North America. We noticed an $\sim 92 \%$ increase in slope to 0.75 when comparing the spatial inhomogeneity adjusted in situ measurements with the OMI ground-level $\mathrm{SO}_{2}$ (red circles in Fig. 2). In comparison to previous studies, Lee et al. (2011), comparing ground-level $\mathrm{SO}_{2}$ mixing ratios derived from SCIAMACHY 


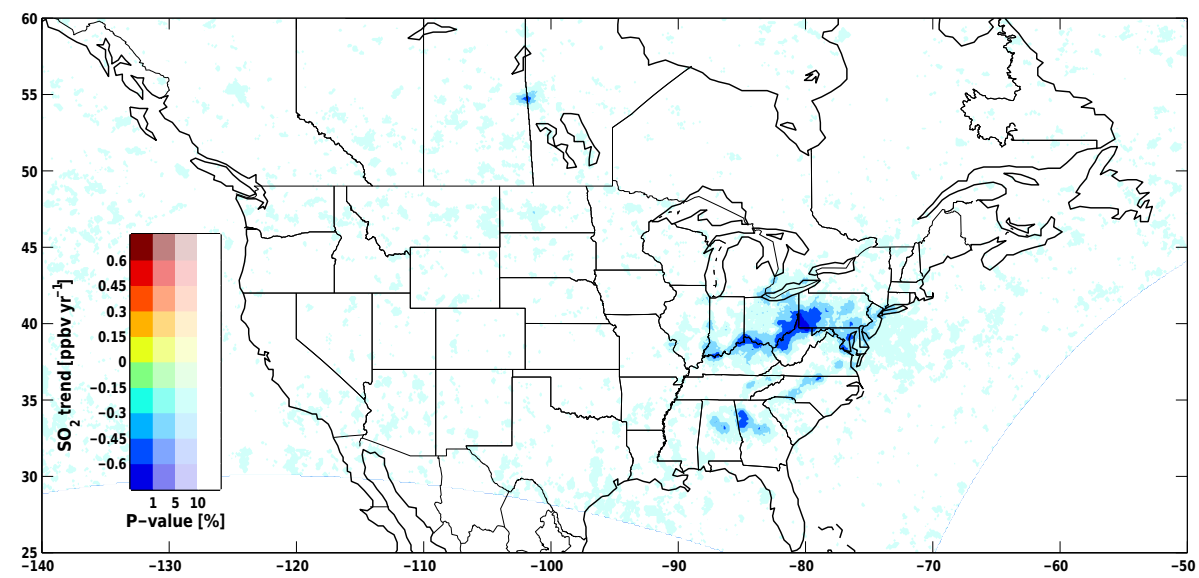

Figure 3. Spatial distribution of the OMI-derived surface $\mathrm{SO}_{2}$ trend at $0.1^{\circ} \times 0.1^{\circ}$ over North America for the years of 2005-2015. Statistical significance is shown in the form of a two-sided $p$ value, tested against null being the zero trend.

and the OMI with in situ measurements from US-EPA AQS and NAPS monitoring networks over the United States and Canada for the year of 2006, reported slightly higher correlation $(r=0.86$, slope $=0.91$ for SCIAMACHY and $r=0.80$, slope $=0.79$ for the OMI). In their study they used a $15 \mathrm{~km}$ coincidence criterion and included only AQS sites measuring less than $6 \mathrm{ppbv}$ at satellite overpass times. Nowlan et al. (2011) estimated ground-level $\mathrm{SO}_{2}$ from GOME-2 and compared with in situ measurements over North America from the Clear Air Status and Trends Network (CASTNET; $r=0.85)$ and US-EPA AQS and NAPS $(r=0.40)$ for 2008.

We determined the trend in ground-level $\mathrm{SO}_{2}$ from the OMI using the monthly time series from January 2005 to December 2015. Figure 3 illustrates the spatial distribution of the OMI-derived ground-level $\mathrm{SO}_{2}$ trend over North America for the period of 2005-2015. We noticed a strong decreasing trend in ground-level $\mathrm{SO}_{2}$ over the eastern US and Flin Flon in Canada. The observed decrease in ground-level $\mathrm{SO}_{2}$ concentration in the eastern US corresponds to stricter pollution control laws implemented to reduce $\mathrm{SO}_{2}$ emissions and the installation of FGD devices in power plants (Fioletov et al., 2011; Krotkov et al., 2016). Furthermore, we estimated the trend in ground-level $\mathrm{SO}_{2}$ at in situ locations collocated with the OMI. Figure $4 \mathrm{a}$ and $\mathrm{b}$ show the trend in ground-level $\mathrm{SO}_{2}$ from the OMI and collocated in situ measurements over North America for the period of 20052015. Both in situ and OMI-derived ground-level $\mathrm{SO}_{2}$ mixing ratios show a strong decreasing trend over the eastern US mainly at locations close to power plants. Figure $4 \mathrm{c}$ shows the scatter plot of trends in ground-level $\mathrm{SO}_{2}$ from collocated in situ measurements and the OMI. The OMI-derived trends are significantly correlated $(r=0.74)$ with collocated in situ trends. As expected the slope of 0.43 is similar to the absolute concentration slope (Fig. 2) and reveals the difference in absolute trend.
Figure 5 shows the percentage change compared to 2005 in annual mean ground-level $\mathrm{SO}_{2}$ concentration from coincidently sampled OMI and in situ measurements and total $\mathrm{SO}_{2}$ emissions from power plants over the eastern US. The geographical locations of stations considered over the eastern US are shown inside the blue color box within the inset map. Both OMI and in situ measurements show $-81 \pm 19 \%$ and $-86 \pm 13 \%$ decreases in ground-level $\mathrm{SO}_{2}$ over the eastern US, respectively. Earlier OMI $\mathrm{SO}_{2}$ column studies reported $40 \%$ (Fioletov et al., 2011) and $80 \%$ (Krotkov et al., 2016) decreases near power plants in the eastern US and Ohio River Valley for the periods of 2005-2010 and 2005-2015, respectively. Furthermore, we derived a decrease of $64 \pm 18 \%$ from spatially averaged OMI-derived ground-level $\mathrm{SO}_{2}$ (Fig. 3) over the eastern US from the entire domain (blue box in Fig. 5). The observed decrease in ground-level $\mathrm{SO}_{2}$ from OMI and in situ measurements is in agreement with the US EPA reported decrease of about $70 \%$ in total US $\mathrm{SO}_{2}$ emissions (https://www3.epa.gov/airtrends/aqtrends.html). Figure 6 shows that bottom-up $\mathrm{SO}_{2}$ emissions and OMI-derived ground-level $\mathrm{SO}_{2}$ concentrations are temporally correlated even for larger individual point sources, namely the Bowen power plant $\left(34.13^{\circ} \mathrm{N}, 84.92^{\circ} \mathrm{W}\right)$, USA, and Flin Flon copper smelter $\left(54.77^{\circ} \mathrm{N}, 101.88^{\circ} \mathrm{W}\right)$, Canada. The bottom-up emissions data for these sites are obtained from the US EPA (2016) and National Pollutant Release Inventory (NPRI, 2017), respectively.

Recently Philip et al. (2014) analyzed the $\mathrm{PM}_{2.5}$ chemical composition over North America from the satellite data and reported that sulfate aerosols contribute $\sim 30 \%$ in ground-level $\mathrm{PM}_{2.5}$ mass concentration over the eastern US. Here, the ground-level sulfate $\mathrm{PM}_{2.5}$ mass concentration is estimated by applying the sulfate fraction from Philip et al. (2014) to the total $\mathrm{PM}_{2.5}$ mass concentration inferred using the method of van Donkelaar et al. (2010), which uses information from satellites, models and monitors. Fig- 
(a) In situ

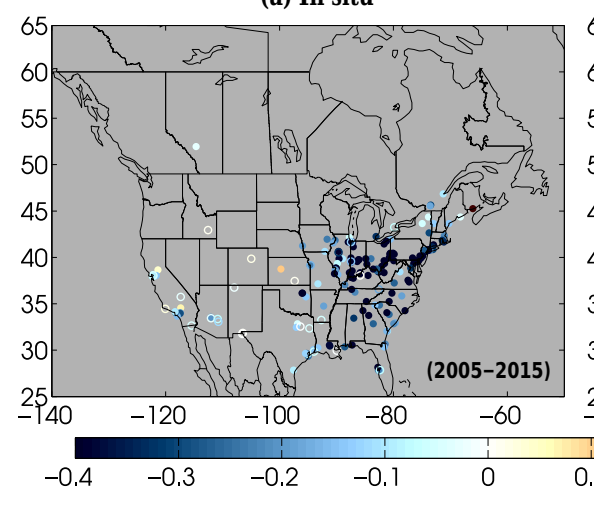

(b) OMI

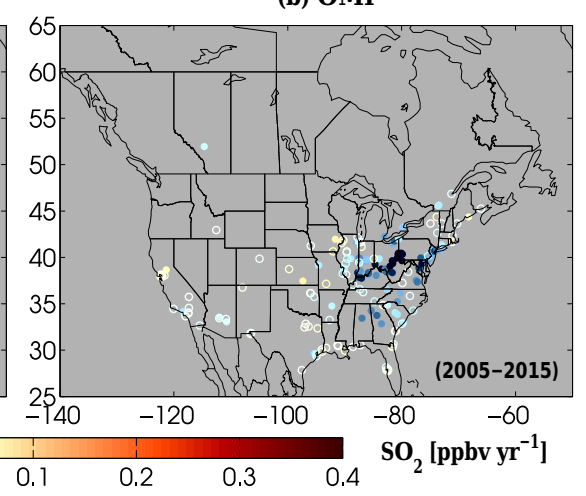

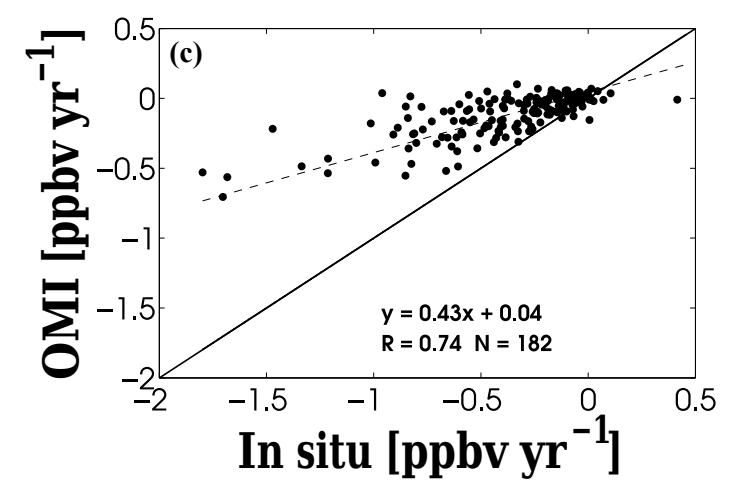

Figure 4. Trends in ground-level $\mathrm{SO}_{2}$ for the period of 2005-2015. Panels (a, b) show trends inferred from in situ measurements at the OMI overpass and from the OMI for the period of 2005-2015. The filled circle represents where trend $p$ values $<0.05$ and trend $p$ values $>0.05$ are shown as empty circles. Panel (c) contains scatter plots of trends for the period of 2005-2015.

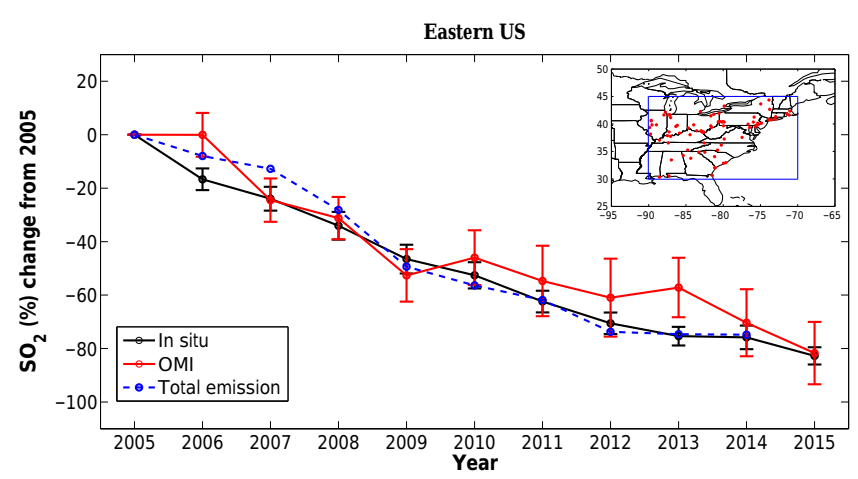

Figure 5. Percent change in the ground-level $\mathrm{SO}_{2}$ mixing ratio from 2005 over the eastern US and southern Ontario, Canada. The in situ and OMI ground-level $\mathrm{SO}_{2}$ percent change are shown in black and red color, respectively. Blue circles show changes in total $\mathrm{SO}_{2}$ emissions. The locations of in situ measurement stations over the eastern US and southern Ontario, Canada (blue box), are shown in the inset map. The error bars represent the 1 standard error of the mean.

ure 7 shows the spatial distribution of $\mathrm{OMI} \mathrm{SO}_{2}$ vertical column density (panel a) and sulfate $\mathrm{PM}_{2.5}$ mass concentration (panel b) over the eastern US for the period of 2005-2008. The locations of large (> $\left.18.98 \mathrm{kt}^{\mathrm{SOO} 2}\right] \mathrm{yr}^{-1}$ in 2006) power plants (largest contributor to $\mathrm{SO}_{2}$ emissions) and 20052008 average boundary-layer winds from an ECMWF (European Center for Medium range Weather Forecasting) reanalysis (Dee et al., 2011) are overlaid on the plots as circles and arrows, respectively. This demonstrates that $\mathrm{SO}_{2}$ VCD influences air quality locally due to its shorter atmospheric lifetime. However, sulfate $\mathrm{PM}_{2.5}$, with a longer atmospheric lifetime, influences air quality locally as well as downwind through long-range transport. It is evident from Fig. 7 that column $\mathrm{SO}_{2}$ and sulfate $\mathrm{PM}_{2.5}$ hotspots are collocated around and downwind of power plant locations. There is only a moderate spatial correlation $(r=0.60)$ between OMI $\mathrm{SO}_{2}$ and sulfate $\mathrm{PM}_{2.5}$, but given that sulfate is largely a secondary pollutant, this is not surprising. It was also found that there is a saturation effect at high $\mathrm{SO}_{2}$ VCDs (Fig. S4).

\section{Conclusions}

We examined the spatial and temporal characteristics of the ground-level $\mathrm{SO}_{2}$ concentration from the OMI over North America during the period from 2005 to 2015. OMI-derived ground-level $\mathrm{SO}_{2}$ concentrations and trends correlate well with in situ measurements ( $r=0.61$ and 0.74 , respectively), with a significant bias in slope. Once the in situ observa- 

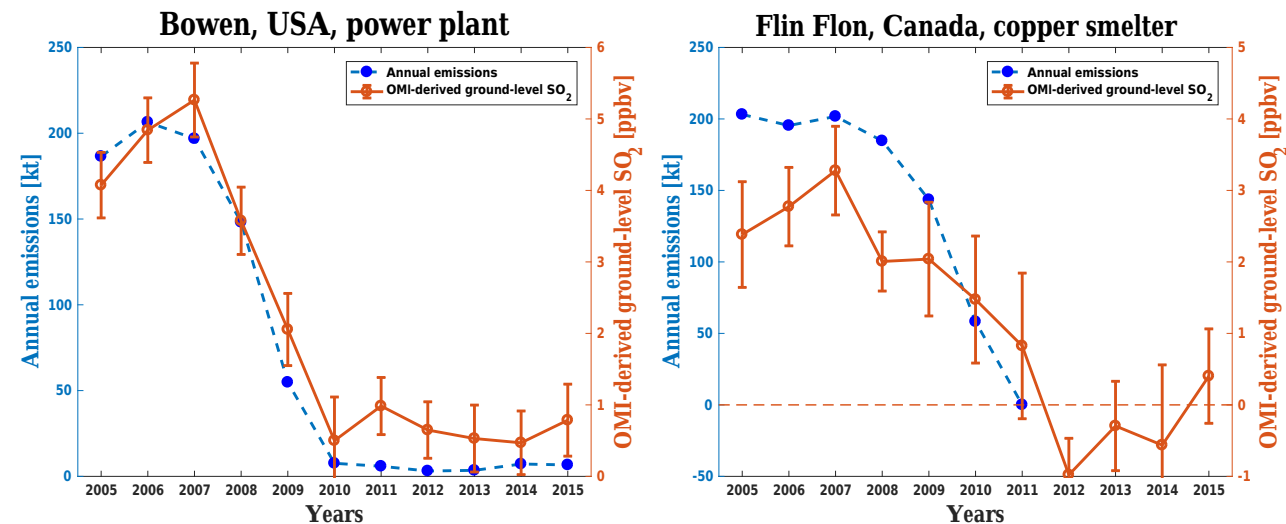

Figure 6. Time series of bottom-up annual $\mathrm{SO}_{2}$ emissions and OMI-derived ground-level $\mathrm{SO}_{2}$ concentrations for Bowen power plant $\left(34.13^{\circ} \mathrm{N}, 84.92^{\circ} \mathrm{W}\right)$, USA, and Flin Flon copper smelter $\left(54.77^{\circ} \mathrm{N}, 101.88^{\circ} \mathrm{W}\right)$, Canada. The dashed orange line represents the zero line in the Flin Flon, Canada, plot. Bottom-up $\mathrm{SO}_{2}$ emissions data are not available after 2011 due to the closure of Flin Flon copper smelter. The error bars represent the 1 standard error of the mean.
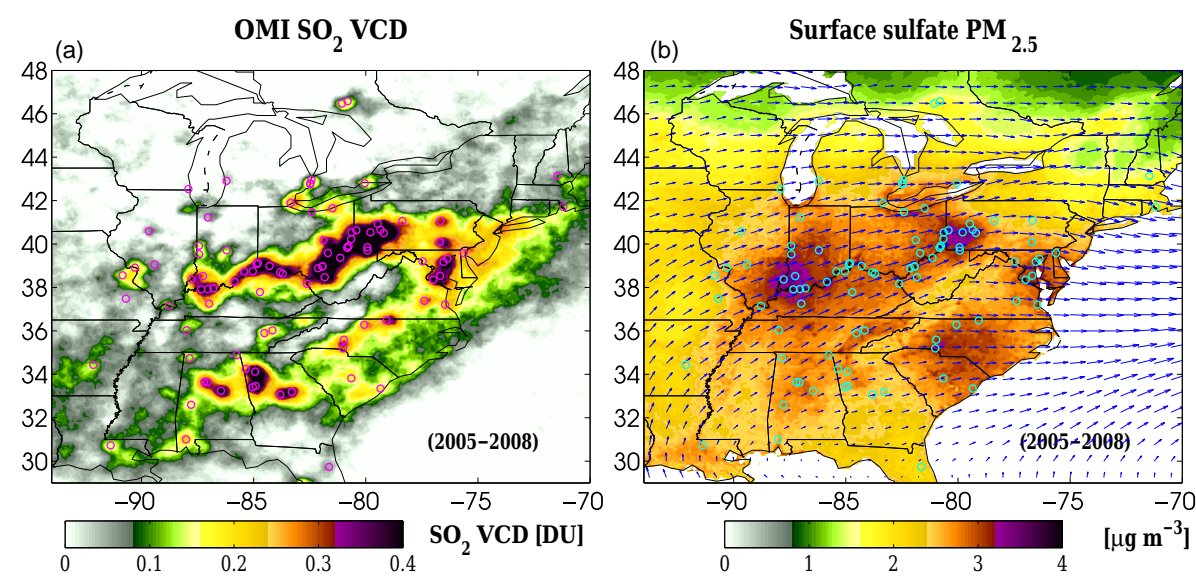

Figure 7. Spatial distribution of (a) satellite-derived $\mathrm{SO}_{2}$ vertical column density (VCD) and (b) sulfate $\mathrm{PM}_{2.5}$ mass concentration over the eastern US and southern Ontario, Canada. The power plant locations overlaid on both panels are shown as circles. ECMWF model-derived ground-level winds overlaid on the sulfate $\mathrm{PM}_{2.5}$ mass concentration map are shown with arrows.

tions are adjusted, based on nested GEM-MACH model results, to account for the spatial sampling differences between the in situ and OMI spatial resolution there is a notable increase $(\sim 92 \%)$ in slope to a value of 0.75 . The observed reduction in ground-level $\mathrm{SO}_{2}$ concentration from the OMI $(-81 \pm 19 \%)$ is consistent with in situ measurements $(-86 \pm 13 \%)$ over the eastern US for the period of $2005-$ 2015. The observed decreasing trend in ground-level $\mathrm{SO}_{2}$ could lead to considerable reduction in sulfate aerosols, and thus play a major role in improving air quality, thereby minimizing its deleterious health impact. The long-term spatial distribution maps of ground-level $\mathrm{SO}_{2}$ from the OMI provide policy-makers with $\mathrm{SO}_{2}$ pollution monitoring at locations where ground measurements are not available. Future satellite missions like TEMPO (Tropospheric Emissions: Monitoring Pollution) will provide better coverage of $\mathrm{SO}_{2}$, and other pollutants, as it will have higher spatial resolution and hourly frequency over the North American continent during daytime (especially the USA and parts of Canada). Also, the TROPOspheric Monitoring Instrument (TROPOMI) is scheduled to launch in 2017 and will provide daily global coverage of tropospheric $\mathrm{SO}_{2}$ and other pollutants, with a high spatial resolution of $7 \mathrm{~km} \times 7 \mathrm{~km}$.

Data availability. The OMI operational principal component analysis (PCA) $\mathrm{SO}_{2}$ product (OMSO2 v1.2.0) was obtained from the NASA Goddard Earth Sciences (GES) Data and Information Services Center (DISC) (http://disc.sci.gsfc.nasa.gov/Aura/ data-holdings/OMI/omso2_v003.shtml). The in situ $\mathrm{SO}_{2}$ measurements were obtained from the Air Quality System (AQS) network of the US EPA (http://www.epa.gov/ttn/airs/airsaqs/detaildata/ downloadaqsdata.htm) and Environment and Climate Change Canada's National Air Pollution Surveillance (NAPS) network (http://maps-cartes.ec.gc.ca/rnspa-naps/data.aspx). The bottom-up 
emissions data were obtained from the US EPA (2016) (http:// www.epa.gov/air-emissions-inventories) and the National Pollutant Release Inventory (NPRI, 2017) (http://www.ec.gc.ca/inrp-npri/ default.asp?lang=En\&n=0EC58C98-). The OMI-SO2 data used in this study can be made available on request (Shailesh K. Kharol and Chris A. McLinden, Environment and Climate Change Canada, Toronto, Ontario, Canada).

\section{The Supplement related to this article is available online at doi:10.5194/acp-17-5921-2017-supplement.}

Competing interests. The authors declare that they have no conflict of interest.

Acknowledgements. We acknowledge the National Aeronautics and Space Administration (NASA) for the availability of OMI $\mathrm{SO}_{2}$ tropospheric column data. We would like to thank the Natural Sciences and Engineering Research Council of Canada (NSERC) for funding support.

Edited by: A. Schmidt

Reviewed by: two anonymous referees

\section{References}

Boys, B. L., Martin, R. V., van Donlelaar, A., MacDonell, R. J., Hsu, N. C., Cooper, M. J., Yantosca, R. M., Lu, Z., Streets, D. G., Zhang, Q., and Wang, S. W.: Fifteen-year global time series of satellite-derived fine particulate matter, Environ. Sci. Technol., 48, 11109-11118, 2014.

Chinn, S., Florey, C. du V., Baldwin, I. G., and Gorgol, M.: The Relation of Mortality in England and Wales 1969-73 to Measurements of Air Pollution, J. Epidemiol. Commun. H., 35, 174-179, 1981.

Côté, J., Gravel, S., Méthot, A., Patoine, A., Roch, M., and Staniforth, A.: The operational CMC-MRB Global Environmental Multiscale (GEM) model. Part 1: Design considerations and formulation, Mon. Weather Rev., 126, 1373-1395, 1998.

Dee, D. P., Uppala, S. M., Simmons, A. J., Berrisford, P., Poli, P., Kobayashi, S., Andrae, U., Balmaseda, M. A., Balsamo, G., Bauer, P., Bechtold, P., Beljaars, A. C. M., van de Berg, L., Bidlot, J., Bormann, N., Delsol, C., Dragani, R., Fuentes, M., Geer, A. J., Haimberger, L., Healy, S. B., Hersbach, H., Holm, E. V., Isaksen, L., Kallberg, P., Kohler, M., Matricardi, M., McNally, A. P., Monge-Sanz, B. M., Morcrette, J.-J., Park, B.-K., Peubey, C., de Rosnay, P., Tavolato, C., Thepaut, J.-N., and Vitart, F.: The ERA-Interim reanalysis: configuration and performance of the data assimilation system, Q. J. Roy. Meteor. Soc., 137, 553-597, 2011.

Dentener, F., Drevet, J., Lamarque, J. F., Bey, I., Eickhout, B., Fiore, A. M., Hauglustaine, D., Horowitz, W. W., Krol, M., Kulshrestha, U. C., Lawrence, M., Galy-Lacaux, C., Rast, S., Shindell, D., Stevenson, D., Van Noije, T., Atherton, C., Bell, N., Bergman, D., Butler, T., Cofala, J., Collins, B., Doherty, R., Ellingsen, K., Galloway, J., Gausee, M., Montanaro, V., Müller,
J. F., Pitari, G., Rodriguez, J., Sanderson, M., Solmon, F., Strahan, S., Schultz, M., Sudo, K., Szopa, S., and Wild, O.: Nitrogen and sulfur deposition on regional and global scales: a multimodel evaluation, Global Biogeochem. Cy., 20, GB4003, doi:10.1029/2005GB002672, 2006.

Derriennic, F., Richardson, S., Mollie, A., and Lellouch, J.: Shortterm effects of sulphur dioxide pollution on mortality in two French cities, Int. J. Epidemiol., 18, 186-197, 1989.

EPA: Air Emissions Inventories, U.S. Environmental Protection Agency, Durham, NC, USA, available online at: https://www. epa.gov/air-emissions-inventories, last access: 15 October 2016.

Fioletov, V. E., McLinden, C. A., Krotkov, N., Moran, M. D., and Yang, K.: Estimation of $\mathrm{SO}_{2}$ emissions using OMI retrievals, Geophys. Res. Lett., 38, L21811, doi:10.1029/2011GL049402, 2011.

Fioletov, V. E., McLinden, C. A., Krotkov, N., Yang, K., Loyola, D. G., Valks, P., Theys, N., Van Roozendael, M., Nowlan, C. R., Chance, K., Liu, X., Lee, C., and Martin, R. V.: Application of OMI, SCIAMACHY, and GOME-2 satellite $\mathrm{SO}_{2}$ retrievals for detection of large emission sources, J. Geophys. Res.-Atmos., 118, 11399-11418, 2013.

Fioletov, V. E., McLinden, C. A., Krotkov, N., and Li, C.: Lifetimes and emissions of $\mathrm{SO}_{2}$ from point sources estimated from OMI, Geophys. Res. Lett., 42, 1969-1976, 2015.

Fioletov, V. E., McLinden, C. A., Krotkov, N., Li, C., Joiner, J., Theys, N., Carn, S., and Moran, M. D.: A global catalogue of large $\mathrm{SO}_{2}$ sources and emissions derived from the Ozone Monitoring Instrument, Atmos. Chem. Phys., 16, 11497-11519, doi:10.5194/acp-16-11497-2016, 2016.

Gong, W., Dastoor, A. P., Bouchet, V. S., Gong, S.-L., Makar, P. A., Moran, M. D., Pabla, B., Menard, S., Crevier, L.-P., Cousineau, S., and Venkatesh, S.: Cloud processing of gases and aerosols in a regional air quality model (AURAMS), Atmos. Res., 82, 248275, 2006.

Gong, W., Makar, P. A., Zhang, J., Milbrandt, J., Gravel, S., Hayden, K. L., Macdonald, A. M., and Leaith, W. R.: Modelling aerosolcloud-meteorology interaction: a case study with a fully coupled air quality model (GEM-MACH), Atmos. Environ., 115, 695715, 2015.

Hand, J. L., Schichtel, B. A., Malm, W. C., and Pitchford, M. L.: Particulate sulfate ion concentration and $\mathrm{SO}_{2}$ emission trends in the United States from the early 1990s through 2010, Atmos. Chem. Phys., 12, 10353-10365, doi:10.5194/acp-1210353-2012, 2012.

Hatzakis, A., Katsouyanni, K., Kalandidi, A., Day, N., and Trichopoulos, D.: Short-term effects of air pollution on mortality in Athens, Int. J. Epidemiol., 15, 73-81, 1986.

IPCC: Climate Change 2013: The Physical Science Basis. Contribution of Working Group I to the Fifth Assessment Report of the Intergovernmental Panel on Climate Change, edited by: Stocker, T. F., Qin, D., Plattner, G.-K., Tignor, M., Allen, S. K., Boschung, J., Nauels, A., Xia, Y., Bex, V., and Midgley, P. M., Cambridge University Press, Cambridge, United Kingdom and New York, NY, USA, 1535 pp., 2013.

Kelly, J., Makar, P. A., and Plummer, D. A.: Projections of mid-century summer air-quality for North America: effects of changes in climate and precursor emissions, Atmos. Chem. Phys., 12, 5367-5390, doi:10.5194/acp-12-5367-2012, 2012. 
Kharol, S. K., Martin, R. V., Philip, S., Boys, B., Lamsal, L. N., Jerrett, M., Brauer, M., Crouse, D. L., McLinden, C., and Burnett, R. T.: Assessment of the magnitude and recent trends in satellitederived ground-level nitrogen dioxide over North America, Atmos. Environ., 118, 236-245, 2015.

Krotkov, N. A., Carn, S. A., Krueger, A. J., Bhartia, P. K., and Yang, $\mathrm{K}$.: Band residual difference algorithm for retrieval of $\mathrm{SO}_{2}$ from the Aura Ozone Monitoring Instrument (OMI), IEEE T. Geosci. Remote, 44, 1259-1266, 2006.

Krotkov, N. A., McLinden, C. A., Li, C., Lamsal, L. N., Celarier, E. A., Marchenko, S. V., Swartz, W. H., Bucsela, E. J., Joiner, J., Duncan, B. N., Boersma, K. F., Veefkind, J. P., Levelt, P. F., Fioletov, V. E., Dickerson, R. R., He, H., Lu, Z., and Streets, D. G.: Aura OMI observations of regional $\mathrm{SO}_{2}$ and $\mathrm{NO}_{2}$ pollution changes from 2005 to 2015, Atmos. Chem. Phys., 16, 46054629, doi:10.5194/acp-16-4605-2016, 2016.

Krzyzanowski, M. and Wojtyniak, B.: Ten-year Mortality in Sample of an adult Population in relation to air pollution, J. Epidemiol. Commun. H., 36, 262-268, 1982.

Lamsal, L. N., Martin, R. V., van Donkelaar, A., Steinbacher, M., Celarier, E. A., Bucsela, E., Dunlea, E. J., and Pinto, J. P.: Ground-level nitrogen dioxide concentrations inferred from the satellite-borne Ozone Monitoring Instrument, J. Geophys. Res., 113, D16308, doi:10.1029/2007JD009235, 2008.

Lee, C., Martin, R. V., van Donkelaar, A., Lee, H., Dickerson, R. R., Hains, J. C., Krotkov, N., Richter, A., Vinnikov, K., and Schwab, J. J.: $\mathrm{SO}_{2}$ emissions and lifetimes: Estimates from inverse modeling using in situ and global, space-based (SCIAMACHY and OMI) observations, J. Geophys. Res., 116, D06304, doi:10.1029/2010JD014758, 2011.

Lee, C. J., Martin, R. V., Henze, D. K., Brauer, M., Cohen, A., and van Donkelaar, A.: Response of global particulate-matter-related mortality to changes in local precursor emissions, Environ. Sci. Technol., 49, 4335-4344, 2015.

Lelieveld, J., Evans, J. S., Fnais, M., Giannadaki, D., and Pozzer, A.: The contribution of outdoor air pollution sources to premature mortality on a global scale, Nature, 525, 367-371, 2015.

Levelt, P. F., van den Oord, G. H. J., Dobber, M. R., Malkki, A., Visser, H., de Vries, J., Stammes, P., Lundell, J. O. V., and Saari, H.: The Ozone Monitoring Instrument, IEEE T. Geosci. Remote, 44, 1093-1101, 2006.

Li, C., Joiner, J., Krotkov, N. A., and Bhartia, P. K.: A fast and sensitive new satellite $\mathrm{SO}_{2}$ retrieval algorithm based on principal component analysis: Application to the ozone monitoring instrument, Geophys. Res. Lett., 40, 6314-6318, doi:10.1002/2013GL058134, 2013.

McLinden, C. A., Fioletov, V., Boersma, K. F., Kharol, S. K., Krotkov, N., Lamsal, L., Makar, P. A., Martin, R. V., Veefkind, J. P., and Yang, K.: Improved satellite retrievals of $\mathrm{NO}_{2}$ and $\mathrm{SO}_{2}$ over the Canadian oil sands and comparisons with surface measurements, Atmos. Chem. Phys., 14, 3637-3656, doi:10.5194/acp-14-3637-2014, 2014

McLinden, C. A., Fioletov, V., Shephard, M. W., Krotkov, N., Li, C., Martin, R. V., Moran, M. D., and Joiner, J.: Space-based detection of missing sulfur dioxide sources of global air pollution, Nat. Geosci., 9, 496-500, 2016a.

McLinden, C. A., Fioletov, V. E., Krotkov, N. A., Li, C., Boersma, K. F., and Adams, C.: A decade of change in $\mathrm{NO}_{2}$ and $\mathrm{SO}_{2}$ over the Canadian Oil Sands as seen from space, Environ. Sci. Technol., 50, 331-337, 2016b.

Moran, M. D., Menard, S., Talbot, D., Huang, P., Makar, P. A., Gong, W., Landry, H., Gravel, S., Gong, S., Crevier, L.-P., Kallaur, A., and Sassi, M.: Particulate-matter forecasting with GEM-MACH15, a new Canadian operational air quality forecast model, in: Air Pollution Modelling and its Application XX, edited by: Steyn, D. G. and Rao, S. T., Springer, Dordrecht, 289293, 2010.

Nowlan, C. R., Liu, X., Chance, K., Cai, Z., Kurosu, T. P., Lee, C., and Martin, R. V.: Retrievals of sulfur dioxide from the Global Ozone Monitoring Experiment 2 (GOME-2) using an optimal estimation approach: Algorithm and initial validation, J. Geophys. Res., 116, D18301, doi:10.1029/2011JD015808, 2011.

Nowlan, C. R., Martin, R. V., Philip, S., Lamsal, L. N., Krotkov, N. A., Marais, E. A., Wang, S., and Zhang, Q.: Global dry deposition of nitrogen dioxide and sulfur dioxide inferred from spacebased measurements, Global Biogeochem. Cy., 28, 1025-1043, doi:10.1002/2014GB004805, 2014.

NPRI: National Pollutant Release Inventory datasets, Environment and Climate Change Canada, Gatineau, QC, Canada, available at: http://www.ec.gc.ca/inrp-npri/default.asp?lang=En\&n= 0EC58C98-, last access: 1 March 2017.

Philip, S., Martin, R. V., van Donkelaar, A., Lo, J. W.-H., Wang, Y., Chen, D., Zhang, L., Kasibhatla, P. S., Wang, S., Zhang, Q., Lu, Z., Streets, D. G., Bittman, S., and Macdonald, D. J.: Global chemical composition of ambient fine particulate matter for exposure assessment, Environ. Sci. Technol., 48, 13060-13068, 2014.

van Donkelaar, A., Martin, R. V., Leaitch, W. R., Macdonald, A. M., Walker, T. W., Streets, D. G., Zhang, Q., Dunlea, E. J., Jimenez, J. L., Dibb, J. E., Huey, L. G., Weber, R., and Andreae, M. O.: Analysis of aircraft and satellite measurements from the Intercontinental Chemical Transport Experiment (INTEX-B) to quantify long-range transport of East Asian sulfur to Canada, Atmos. Chem. Phys., 8, 2999-3014, doi:10.5194/acp-8-2999-2008, 2008.

van Donkelaar, A., Martin, R. V., Brauer, M., Kahn, R. A., Levy, R. C., Verduzco, C., and Villeneuve, P. J.: Global estimates of ambient fine particulate matter concentrations from satellitebased aerosol optical depth: development and application, Environ. Health Persp., 118, 847-855, doi:10.1289/ehp.0901623, 2010.

Vet, R., Artz, R. S., Carou, S., Shaw, M., Ro, C.-U., Aas, W., Baker, A., Bowersox, V. C., Dentener, F., Galy-Lacaux, C., Hou, A., Pienaar, J. J., Gillett, R., Forti, M. C., Gromov, S., Hara, H., Khodzher, T., Mahowald, N. M., Nickovic, S., Rao, P. S. P., and Reid, N. W.: A global assessment of precipitation chemistry and deposition of sulfur, nitrogen, sea salt, base cations, organic acids, acidity and pH, and phosphorus, Atmos. Environ., 93, 3 100, 2014.

Yang, K., Krotkov, N. A., Krueger, A. J., Carn, S. A., Bhartia, P. K., and Levelt, P. F.: Retrieval of large volcanic $\mathrm{SO}_{2}$ columns from the Aura Ozone Monitoring Instrument: Comparison and limitations, J. Geophys. Res., 112, D24S43, doi:10.1029/2007JD008825, 2007. 